\title{
‥
}

RESEARCH AND EDUCATION

\section{Fracture load of complete-arch implant-supported prostheses reinforced with nylon-silica mesh: An in vitro study}

\author{
Fernanda de Cássia Papaiz Gonçalves, DDS, MS, PhD, ${ }^{a}$ Marina Amaral, DDS, MS, PhD, \\ Alexandre Luiz Souto Borges, DDS, MS, PhD, ${ }^{c}$ Luiz Fernando Martins Gonçalves, Eng, ${ }^{d}$ and \\ Tarcisio José de Arruda Paes-Junior, DDS, MS, $\mathrm{PhD}^{\mathrm{e}}$
}

Tissue-supported dentures may cause discomfort in patients and present support, stability, and retention challenges. ${ }^{1}$ The use of implant-supported prostheses brings better function to patients with complete edentulism, improving masticatory efficency. ${ }^{1}$ But the masticatory loads on implants must be controlled and well distributed. Loads that are higher than is acceptable to the bone lead to resorption around implants of approximately 0.06 to $0.08 \mathrm{~mm}$ per year. ${ }^{2,3}$ The load distribution depends directly on the design of the prosthesis and on the passive adjustment of components and occlusion with the opposite arch. ${ }^{4-6}$ The materials used in the fabrication of the implants and prosthesis also play an important role in load distribution.

The incidence of mechanical complications or failure with implant-based treatments has been described and is mostly associated with overloading, which may manifest prostheses.

\begin{abstract}
Statement of problem. Complete-arch implant-supported prostheses without a framework have a high risk of failure: a straightforward and inexpensive reinforcement material, such as nylon mesh, could improve their longevity.
\end{abstract}

Purpose. The purpose of this in vitro study was to evaluate a nylon-silica mesh compound on the fracture strength of acrylic resin and the fracture load of complete-arch implant-supported

Material and methods. Twenty-four complete mandibular arch implant-supported prostheses were divided into 2 groups according to cantilever length (molar and premolar) and subdivided into another 2 subgroups according to the presence or absence of reinforcing mesh. The specimens were submitted to a maximum load-to-fracture test in a universal testing machine, with a $100-\mathrm{N}$ load cell, a $2 \mathrm{~mm} / \mathrm{min}$ crosshead speed, and a spherical metal tip diameter of $4 \mathrm{~mm}$ at different points (molar and premolar). These were submitted to 1-way analysis of variance for repeated measurement and the post hoc Tukey multiple comparison test $(\alpha=.05)$.

Results. The mean maximum load \pm standard deviation for the molar group was $393.4 \pm 95.0 \mathrm{~N}$ with reinforcement and $305.4 \pm 76.3 \mathrm{~N}$ without reinforcement $(P=.02)$; and for the premolar group was $1083.3 \pm 283.7 \mathrm{~N}$ with reinforcement and $605.3 \pm 90.5 \mathrm{~N}$ without reinforcement $(P=.001)$.

Conclusions. Reinforcement with nylon mesh increased the mean maximum load of implantsupported complete-arch prostheses at both cantilever lengths. The cantilever to the premolar $(5 \mathrm{~mm})$ presented the highest maximum load values to fracture. (J Prosthet Dent 2018;119:606-10)

in damage to the implants, to the implant-supported prostheses, or to the bone. ${ }^{8}$ Fracture or loosening of fixation screws, fracture of occlusal veneering materials, fracture of prostheses, continuous crestal bone loss, and fracture of implants as a consequence of bone loss have been reported. ${ }^{8,9}$ Therefore, reinforcement fibers have

Supported by São Paulo Research Foundation (FAPESP) grant no. 2011/07334-6.

${ }^{a}$ Professor, Postdoctoral Program, Institute of Aeronautics Technology (ITA), São José dos Campos, Brazil.

${ }^{\mathrm{b}}$ Assistant Professor, Dental Prostheses, Department of Dentistry, University of Taubaté (UNITAU), Taubaté, Brazil.

${ }^{\mathrm{c} A s s o c i a t e}$ Professor, Department of Dental Materials and Prosthodontics, São Paulo State University (UNESP), Institute of Science and Technology,

São José dos Campos, Brazil.

${ }^{\mathrm{d}}$ Researcher, Engineering, Applications Laboratory, Institute of Aeronautics Technology (ITA), São José dos Campos, Brazil.

${ }^{\mathrm{e}}$ Associate Professor, Department of Dental Materials and Prosthodontics, São Paulo State University (UNESP), Institute of Science and Technology,

São José dos Campos, Brazil. 


\section{Clinical Implications}

The use of nylon-silica mesh to reinforce complete-arch prostheses supported by implants may decrease fracture in the cantilever area when a metal framework is not used.

been added to acrylic resin to improve the mechanical properties of the prosthesis ${ }^{10-13}$ and to decrease the risk of fracture. Glass fibers, nylon mesh, and metal mesh have been embedded in the resin mass. ${ }^{14,15} \mathrm{~A}$ nylon mesh with embedded silica was recently developed with good improvements in strength in interim-fixed prostheses fabricated in bisacrylic resin. ${ }^{15}$

The increase in the cantilever length of implantsupported prostheses is one of the factors that can lead to bone loss around the implants and to prosthesis fracture. ${ }^{16,17}$ Cantilever length should not exceed $20 \mathrm{~mm}$ (with better results when it is less than $15 \mathrm{~mm}$ ), ${ }^{18}$ and occlusal contacts should be adjusted to reduce forces in the cantilever region. ${ }^{18,19}$ The ratio between maximum cantilever length (CL) and anterior-posterior spread and the length of the prosthesis projecting from the most distal implants has been described and is used to estimate the maximum safe cantilever extension. ${ }^{20}$ The use of nylon mesh could improve strength and stress distribution in the cantilever region.

The purpose of this in vitro study was to evaluate the influence of the addition of a modified nylon mesh on the maximum load to fracture of a complete-arch implantsupported prosthesis and the influence of CL for load application. The null hypothesis was that the incorporation of mesh does not increase the maximum load of fracture in complete-arch implant-supported prostheses.

\section{MATERIAL AND METHODS}

Table 1 shows the materials, manufacturers, and batch numbers used in this study. The specimens were prepared based on testing 4 groups $(n=6)$ to maximum load to fracture. A power analysis was performed with software (Open Source Epidemiologic Statistics for Public Health, v3.01) to determine the number of specimens required for testing in each group. The sample size was determined by a preliminary study considering a power of $80 \%$.

The following groups were established: complete-arch implant-supported prosthesis without reinforcement and second premolar CL (WRP); complete-arch implantsupported prosthesis without reinforcement and first molar CL (WRM); complete-arch implant-supported prosthesis with nylon reinforcement and second premolar CL (RP); and complete-arch implant-supported prosthesis with nylon reinforcement and first molar CL (RM).
Table 1. Materials used

\begin{tabular}{|c|c|c|c|}
\hline Material & Commercial Name & Manufacturer & $\begin{array}{l}\text { Batch } \\
\text { No. }\end{array}$ \\
\hline $\begin{array}{l}\text { Heat polymerized } \\
\text { acrylic resin }\end{array}$ & Vipi-Wave & Dental Vipi Ltda & 12964 \\
\hline Implant & $\begin{array}{l}\text { Cortical Screw Master AR-torq } \\
\text { Cone Morse, Porous } \\
\text { NP } 4,0 \times 13\end{array}$ & $\begin{array}{l}\text { Conexão Sistemas } \\
\text { de Próteses }\end{array}$ & 123653 \\
\hline Transfer coping & $\begin{array}{l}\text { Square Micro-Unit Pillar } \\
\text { Transfer }\end{array}$ & $\begin{array}{l}\text { Conexão Sistemas } \\
\text { de Próteses }\end{array}$ & 149305 \\
\hline Implant analog & Implant Analog Micro-Unit & $\begin{array}{l}\text { Conexão Sistemas } \\
\text { de Próteses }\end{array}$ & 147461 \\
\hline Implant abutment & $\begin{array}{l}\text { Abutment Micro-Unit } \\
\text { NP } 2.5\end{array}$ & $\begin{array}{l}\text { Conexão Sistemas } \\
\text { de Próteses }\end{array}$ & 135667 \\
\hline Hexagonal screw & $\begin{array}{l}\text { Hexagonal Screw Micro-Unit } \\
\text { Angled }\end{array}$ & $\begin{array}{l}\text { Conexão Sistemas } \\
\text { de Próteses }\end{array}$ & 148774 \\
\hline Interim cylinder & Interim Pillar Micro-Unit & $\begin{array}{l}\text { Conexão Sistemas } \\
\text { de Próteses }\end{array}$ & 146823 \\
\hline Modified mesh & Nylon 6.0 (CAD-0 Sil) & $\begin{array}{l}\text { Natmar Moldes } \\
\text { e Plásticos Ltda }\end{array}$ & - \\
\hline Denture teeth & Biotone IPN & Dentsply Sirona & CE \\
\hline
\end{tabular}

A replica of a human edentulous mandible molded with industrial silicone (Zetalabor; Zhermack SpA) was used as the standard. From this mold, a polyurethane resin jaw was constructed (F16; Axson Technologies). This material was selected because of its isotropic properties and because its modulus of elasticity is similar to that of human bone (polyurethane $3.6 \mathrm{GPa}$; medullar bone 4.0-4.5 GPa). ${ }^{21,22}$ The polyurethane resin was handled according to the manufacturer's recommendations and was poured into the silicone mold. After 20 minutes, the model was removed from the silicone mold, finished, and polished.

From a master implant-positioning polyurethane model, 5 geometric and equidistant holes were made so that the definitive positions of the implants were parallel to each other and perpendicular to the horizontal plane of the polyurethane resin pad. For drilling, a set of standardized and conventional milling surgery drills was used, coupled with a straight tip (E10C; KaVo do Brasil Ind Com Ltda). The holes were drilled in the sequence suggested by the manufacturer (spearhead drill, followed by 2-, 3-, 3.15-, and 3.5-mm twist drills). The device was attached to a vertical milling machine (B2; Bio-Art Equipamentos Odontológicos Ltda) to prevent angulation differences among the different implants. Five implants with 3-mm exposure length were placed between the bilateral mental foramen. ${ }^{23}$

The implants were placed using a manual surgical ratchet with a torque of $32 \mathrm{Ncm}$. Micro-unit-type prosthetic connections with a $2.5-\mathrm{mm}$ metal strap were then installed on the fasteners with a torque of $20 \mathrm{Ncm}$ with the aid of a progressive mechanical torque wrench (Conexão Sistemas de Próteses), according to the manufacturer's recommendations.

On the template model, transmucosal abutments were inserted and positioned with low-viscosity silicone 


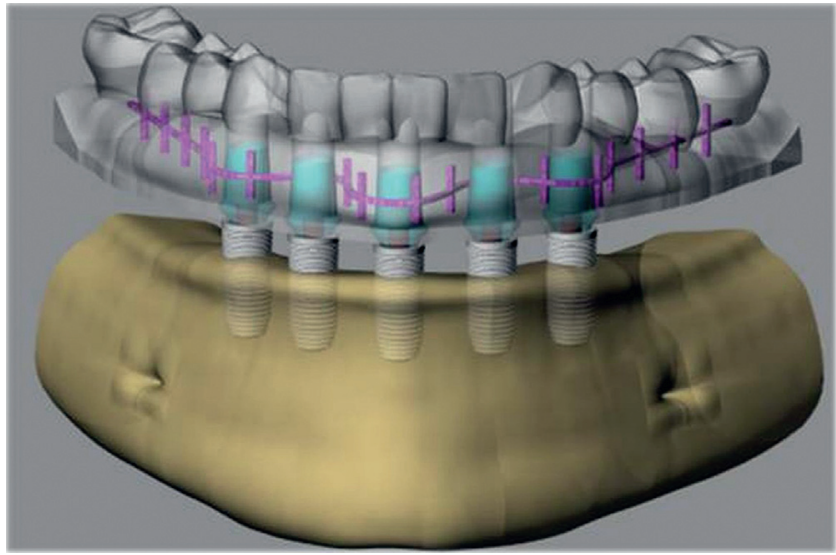

Figure 1. Mesh arrangement around abutments.

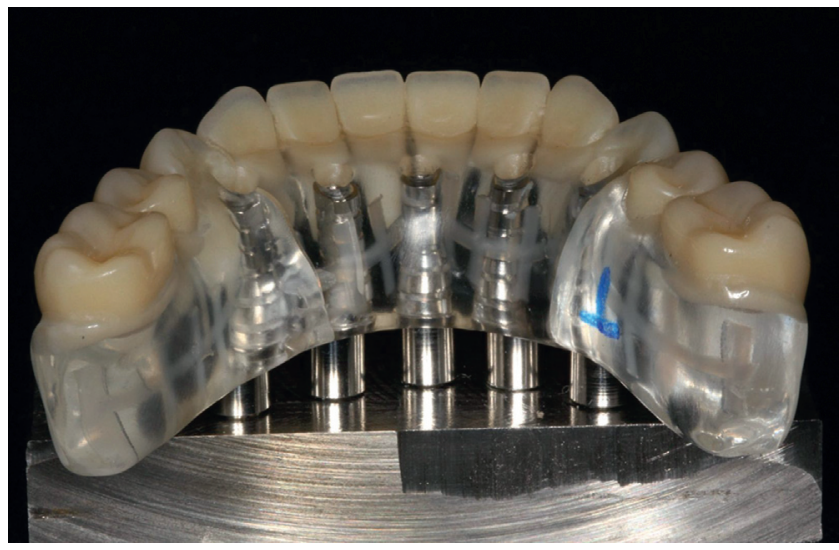

Figure 3. Prosthesis inserted into load-to-fracture fixture.

(Gingifast; Zhermack SpA) to cover the exposed region of the implant. Impression posts were attached to the abutments and initially joined by impression coping to make the impression. A polyvinyl siloxane (Elite HD+; Zhermack SpA) impression was made and, after polymerization, the copings were unscrewed and the tray was removed.

A Type IV gypsum cast (Zero Stone; Dentona) with implant analogs was obtained; the analog micro-unit abutments were screwed to an interim metal cylinder, where a nylon mesh segment was placed (BR 10.2012.028119.8) by alternating between the buccal and lingual sides of the cylinders (Fig. 1). The posterior region of the mesh was joined and stabilized with autopolymerizing acrylic resin (Duralay; Reliance Dental Mfg Co) to prevent mesh displacement during waxing and prosthesis processing.

The 5-mm cantilever groups (RP and WRP) extended to the second premolar and the long, 15-mm cantilever groups (RM and WRM) to the first molar. When the thermally activated acrylic resin reached the dough stage,

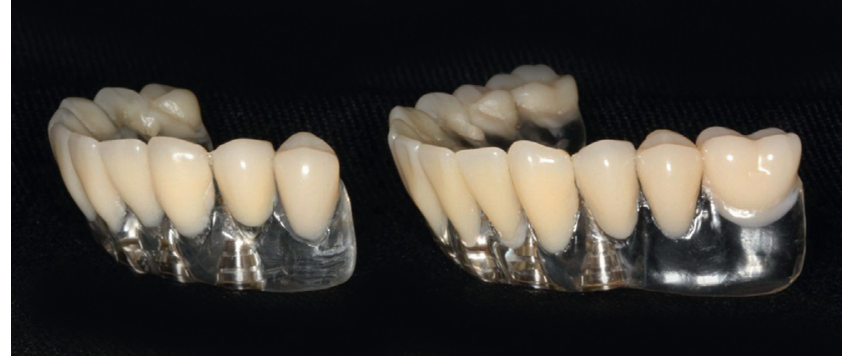

Figure 2. Examples of prosthesis with premolar and molar cantilever extension.

Table 2. Mean values $(\mathrm{N})$ and statistical significance of load-to-fracture data to extension

\begin{tabular}{lc}
\hline Group & Maximum Load-to-fracture \\
\hline Premolar extension & \\
\hline RP & $1083.3 \pm 283.7^{\mathrm{a}}$ \\
\hline WRP & $605.3 \pm 90.5^{\mathrm{b}}$ \\
\hline Molar extension & \\
\hline RM & $393.4 \pm 95.0^{\mathrm{a}}$ \\
\hline WRM & $305.4 \pm 76.3^{\mathrm{b}}$ \\
\hline
\end{tabular}

RM, reinforced molar; RP, reinforced premolar; WRM, without reinforced molar; WRP, without reinforced premolar. ${ }^{*}$ Total, $P=.001$. ${ }^{* *}$ Total, $P=.020$. Superscript letters indicate statistical difference in respective column/row.

it was polymerized in a turntable microwave oven (Continental AW-30; BS Continental da Amazônia Ltda) $(900 \mathrm{~W}$ at $20 \%$ power for 20 minutes, and at $60 \%$ power for an additional 5 minutes). After cooling, the prosthesis was removed and finished with tungsten carbide burs (H251 EF; Komet) (Fig. 2).

The prosthesis with micro-unit analog abutments hand-tightened to $10 \mathrm{Ncm}$ was placed in a metal block $(36 \times 32 \times 18 \mathrm{~mm})$ for the maximum load-to-fracture test (Fig. 3) in a universal testing machine (EMIC DL-1000; EMIC), with a $1000-\mathrm{N}$ load cell and $2 \mathrm{~mm} / \mathrm{min}$ crosshead speed. The load was applied with a 4-mmdiameter spherical metal tip positioned on the occlusal central pit of the molar or premolar. ${ }^{4}$ Values were obtained in newtons $(\mathrm{N})$. All CL data (to molar or premolar) were submitted to 1-way analysis of variance (ANOVA) (presence or absence of reinforcement), and the post hoc Tukey multiple comparison test was applied $(\boldsymbol{\alpha}=.05)$.

\section{RESULTS}

The highest load-to-fracture values were found for the reinforced groups. The presence of reinforced nylon-silica mesh increased the maximum load-to-fracture values independently of the region of loading; the lowest was the cantilever extension (CL), with the RP group showing higher values $(P=.001)$ (Table 2$)$. The ANOVA showed statistical differences for the premolar $(P=.001)$ and molar $(P=.02)$ groups. 


\section{DISCUSSION}

This study evaluated the incorporation of a nylon-silica mesh in a complete-arch implant-supported prosthesis, analogous to what would occur in clinical practice when the interim implant-supported prosthesis is immediately loaded. The null hypothesis was rejected, since the addition of the mesh led to higher load-to-fracture values $(P=.02$ for molar $C L$ group and $P=.001$ for premolar CL group), confirming information from a previous study. ${ }^{15}$

The use of a material with a low elastic modulus such as acrylic resin may help osseointegration during bone healing. In immediately loaded implants, stresses may be absorbed by the prosthetic material and the healing interface protected. ${ }^{3,14}$ The addition of nylon mesh increases the strength of the prosthesis but decreases the elastic modulus, allowing the distribution of stresses generated by mastication.

The load-to-fracture test, similar to that described by Almeida et $\mathrm{al}^{15}$ was used to evaluate the effect of reinforcement with nylon mesh. This test does not fully reproduce the clinical situation, but is efficient in characterizing the effect of reinforcement in specimens, providing comparison with the different groups tested. The results of maximum load to fracture of reinforced prostheses were higher than those of conventional interim complete-arch implant-supported prosthesis for both CLs tested (Table 2). As an additional assessment, a single specimen with a metal bar reinforcement was fabricated and tested and showed maximum load-tofracture values close to those of the nylon-silica meshreinforced prosthesis (nylon-silica mesh premolar: 1083.3 $\pm 283.7 \mathrm{~N}$, molar: $393.4 \pm 95.0 \mathrm{~N}$; metal bar premolar: $1217.5 \mathrm{~N}$, molar: $537.4 \mathrm{~N})$.

These promising results may be explained by the mesh design. Although the design does not present intertwined fibers, it was created and injected in a single body, which facilitated a smooth, 1-way load distribution. ${ }^{15}$ In the present study, reinforcing mesh promoted statistically significant higher values for maximum load to fracture of implant-supported complete-arch dentures, as well as observed for fixed dental prosthesis. ${ }^{15}$

Acrylic resin complete-arch implant-supported prostheses with provisional abutments provide a straightforward interim restoration with good tissue response. However, the mechanical properties of methyl methacrylate polymers have limitations, including relatively low bending resistance, which may contribute to fracture. ${ }^{11,12}$ Fractures associated with fatigue and bending cause approximately $10 \%$ of clinical prosthesis failures. ${ }^{13}$ In the present study, the formation of cracks or fracture of the prosthesis occurred in the region of the last implant (premolar), close to where the load was applied. In the groups including molar extension (longer cantilever), all specimens fractured at the premolars.

The search to reduce such weakness has motivated the development of materials and techniques to enable improvements in the flexural and impact resistance of acrylic resins. ${ }^{17}$ The use of a cantilever and its extension is associated with better stress distribution throughout the system and is fundamental to the longevity of the prostheses. Understanding new techniques for prosthetic reinforcement may enable the application of these techniques and promote the increase in the mechanical strength of devices. Additional in vitro and clinical studies are necessary to evaluate the influence of nylon-silica reinforcement systems around the implant's surface.

\section{CONCLUSIONS}

Within the limitations of this in vitro study the following conclusion was drawn:

1. The incorporation of reinforcing nylon mesh increased maximum load-to-fracture values for both cantilever lengths.

\section{REFERENCES}

1. Brånemark PI. Osseointegration and its experimental background. J Prosthet Dent 1983;50:399-409.

2. Krennmair G, Seemann R, Weinländer M, Krennmair S, Piehslinger E. Clinical outcome and peri-implant findings of four-implant-supported distal cantilevered fixed mandibular prostheses: five-year results. Int J Oral Maxillofac Implants 2013;2:831-40.

3. Lindquist LW, Rockler B, Carlsson GE. Bone resorption around fixtures in edentulous patients treated with mandibular fixed tissue-integrated prostheses. J Prosthet Dent 1988;59:59-63.

4. Mericske-Stern R, Assal P, Mericske E, Burgin W. Occlusal force and oral tactile sensibility measured in partially edentulous patients with ITI implants. Int J Oral Maxillofacial Implants 1995;10:345-53.

5. Carr AB, Gerard DA, Larsen PE. The response of bone in primates around unloaded dental implants supporting prostheses with different levels of fit. J Prosthet Dent 1996;76:500-9.

6. Kan JYK, Rungcharassaeng K, Bohsali K, Goodacre CJ, Lang BR. Clinical methods for evaluating implant framework fit. J Prosthet Dent 1999;81: 7-13.

7. Ciftci $Y$, Canay S. Stress distribution on the metal framework of the implant supported fixed prosthesis using different veneering materials. Int J Prosthodont 2001;14:406-11

8. Misch CE, Bidez MW. Implant protected occlusion: a biomechanical rationale. Compend Cont Educ Dent 1994;15:1330-43.

9. Nishioka RS, Vasconcellos LG, Melo Nishioka GN. Comparative strain gauge analysis of external and internal hexagon, Morse taper, and influence of straight and offset implant configuration. Implant Dent 2011;20:24-32.

10. Sthipho HD. Repair of acrylic resin denture base reinforced with glass fiber. J Prosthet Dent 1998;80:546-50.

11. Woelfel JB. Processing complete dentures. Dent Clin N Am 1977;21:329-38.

12. Gupta A, Tewari RK. Evaluation and comparison of transverse and impact strength of different high strength denture base resins. Indian J Dent Res 2016;27:61-5.

13. Li BB, Xu JB, Cui HY, Lin Y, Di P. In vitro evaluation of the flexural properties of All-on-Four provisional fixed denture base resin partially reinforced with fibers. Dent Mater J 2016;35:264-9.

14. Meric G, Erkmen E, Kurt A, Tunc Y, Eser A. Influence of prosthesis type and material on the stress distribution in bone around implants: a 3-dimensional finite element analysis. J Dent Sci 2011;6:25-32.

15. Almeida CS, Amaral M, de Cássia Papaiz Gonçalves F, de Arruda PaesJunior TJ. Effect of an experimental silica-nylon reinforcement on the fracture load and flexural strength of bisacrylic interim partial fixed dental prostheses. J Prosthet Dent 2016;115:301-5. 
16. Shackleton JL, Carr L, Slabbert JC, Becker PJ. Survival of fixed implantsupported prostheses related to cantilever lengths. J Prosthet Dent 1994;71: 23-6.

17. Ogawa T, Dhaliwal S, Naert I, Mine A, Kronstrom M, Sasaki K, et al. Effect of tilted and short distal implants on axial forces and bending moments in implants supporting fixed dental prostheses: an in vitro study. Int J Prosthodont 2010;23:566-73.

18. Chapman RJ. Principles of occlusion for implant prostheses: guidelines for position, timing, and force of occlusal contacts. Quintessence Int 1989;20: 473-80.

19. Jackson BJ. Occlusal principles and clinical applications for endosseous implants. J Oral Implantol 2003:19:230-4.

20. McAlarney ME, Stavropoulos DN. Determination of cantilever lengthanterior-posterior spread ratio assuming failure criteria to be the compromise of the prosthesis retaining screw-prosthesis joint. Int J Oral Maxillofac Implants 1996;11:331-9.

21. Rubo JH, Souza EAC. Finite element analysis of stress in bone around denta implants. J Oral Implantol 2008;9:407-18.
22. Moretti Neto RT, Tobias R, Hiramatsu DA, Suedam V, Conti PCR, Rubo JH Validation of an experimental polyurethane model for biomechanical studies on implant supported prosthesis: compression tests. J Appl Oral Sci 2011;19:47-51.

23. International Organization for Standardization. ISO 14801. Dentistry Implants - Dynamic fatigue test for endosseous dental implants. Geneva: ISO; 2007. Available at: http://www.iso.org/iso/store.htm.

\section{Corresponding author:}

Dr Tarcisio José de Arruda Paes Junior

Institute of Science and Technology, Sao Paulo State University (UNESP)

Department of Dental Materials and Prosthodontics

Avenue Engenheiro Francisco José Longo 777

São José dos Campos 12245000

BRAZIL

Email: tarcisio@fosjc.unesp.br; tarcisiopaes14@gmail.com

Copyright (C) 2017 by the Editorial Council for The Journal of Prosthetic Dentistry. 